\title{
DIET OF CHACEON NOTIALIS (DECAPODA, BRACHYURA) OFF THE COAST OF RIO GRANDE, RS, BRAZIL
}

\author{
Sergio Santos Domingos ${ }^{1}$; Alessandro Augusto Rogick Athiê $\hat{e}^{2}$ and Carmen Lúcia Del Bianco Rossi- \\ Wongtschowski ${ }^{2}$ \\ ${ }^{1}$ Instituto de Biociências da Universidade de São Paulo \\ (Rua do Matão, travessa 14, 321, 05508-900 São Paulo, SP, Brasil) \\ sergiomoko@hotmail.com \\ ${ }^{2}$ Instituto Oceanográfico da Universidade de São Paulo \\ (Praça do Oceanográfico, 191, 05508-912 São Paulo, SP, Brasil) \\ aleathie@usp.br; cwongski@usp.br
}

There are two species of the genus Chaceon (Geryonidae) inhabiting the southeastern and southern coastal waters of Brazil, Chaceon ramosae Manning, Tavares and Albuquerque, 1989, and Chaceon notialis Manning and Holthuis, 1989, commonly called royal crab and red crab, respectively, otherwise generally known as deep sea crabs. Both species have suffered enormous pressure as a result of deep sea fishing activity in the Brazilian Exclusive Economic Zone (EEZ) (ATHIÊ; ROSSI-WONGTSCHOWSKI, 2004).

Crabs of the genus Chaceon are epibenthonic and inhabit muddy and muddy-sandy bottoms between 100 and $2800 \mathrm{~m}$ isobaths (MANNING; HOLTHUIS, 1989). There is evidence that the species $C$. notialis occurring in Rio Grande coast belongs to the Uruguayan and Argentinean stocks, and thus represents an important resource common to those three countries (ATHIË; ROSSIWONGTSCHOWSKI, 2004).

Studies on the biology of geryonid crabs inhabiting the Brazilian Exclusive Economic Zone (EEZ) are still few. The aim of the present study is to provide preliminary data on the composition of the diet of Chaceon notialis living in the coastal waters off Rio Grande.

The crabs were caught during sampling carried out for the REVIZEE Program (Living Resources in the Exclusive Economic Zone) and also by a commercial fishing vessel; it is important to observe that the collections were not directed specifically to the study of the diet; the specimens collected did however permit a first assessment of the diet of the species.

Sampling of $C$. notialis was carried out by two vessels using different methodologies: specimens were collected by the commercial fishing vessel "Kimpo Maru n ${ }^{\circ} 58^{\prime}$ " using bottom traps baited with fresh heads of Coryphaena hippurus and Katsuwonus

$\overline{\text { Contr. No. } 874}$ do Inst. oceanogr. da Usp. pelamis in the area limited by parallels $34^{\circ} 33.4^{\prime} \mathrm{S}$ and $34^{\circ} 44.0^{\prime} \mathrm{S}$ at depths between 548 and $652 \mathrm{~m}$ during June/July 1999; and by the research vessel "Atlântico Sul", which used a bottom trawl to sample the area located between $33^{\circ} 34.0^{\prime} \mathrm{S}$ and $34^{\circ} 30.7^{\prime} \mathrm{S}$ between 350 and $536 \mathrm{~m}$ isobaths, during March 2002.

A total of 32 specimens of Chaceon notialis was analyzed. First, all the animals sampled were fixed with $10 \%$ buffered formaldehyde and then transferred to $70 \%$ alcohol. For each specimen cephalothorax length (CL) and cephalothorax width (CW) were measured in millimeters and body weight was recorded in grams using a $0.01 \mathrm{~g}$ precision scale. After biometry, the stomachs were extracted and weighed and their contents analyzed once the excess of liquid external to this organ had been wiped off with tissue paper. The fullness level (FL) of the stomachs, which indicates the volume of the contents as a proportion of the maximum volume of the stomach (ZAVALA-CAMIN, 1996), was recorded as a percentage in accordance with the following scale: $\mathrm{FL}=0$ ( $0 \%$ empty), $\mathrm{FL}=1(1 \%-25 \%$ full $), \mathrm{FL}=2$ (26\% - 75\% full) and FL $=3$ (76\% - 100\% full).

The identification of food items was made with the help of specialists from the Instituto Oceanográfico and the Museu de Zoologia, both of the Universidade de São Paulo. Prey was identified to species or to the lowest possible taxonomic level. Items that could not be identified were classified as Undetermined Organic Matter (UOM).

Because of the presence of a great number of items the individual counting of which was difficult, it was decided not to analyze the numerical frequency of the items concerned. Thus, in the present study, the percentage frequency of occurrence (FO\%) and percentage biomass abundance (M\%) (HYSLOP, 1980) for each prey item and prey group were calculated.

From the percentage frequency of occurrence and percentage biomass abundance the alimentary index (AI\%) was calculated using the modified formula of Kawakami and Vazzoler (1989): 


$$
A I \%=\frac{\mathrm{FO} \% \times \mathrm{M} \%}{\sum(\mathrm{FO} \% \times \mathrm{M} \%)} X 100
$$

The alimentary index considers the effect of occurrence and weight because it analyzes both variables at the same time. The analysis of only one variable in the study of the diet (only $\mathrm{FO} \%$, for example) could over- or under-estimate the importance of a given prey item.

In all, 24 foreguts of $C$. notialis collected by bottom trawl and 8 foreguts of $C$. notialis collected with baited bottom traps were analyzed.

Most of the stomachs $(66 \%)$ had FL $=1(1 \%$ - $25 \%$ full), $9 \%$ of them were empty (FL $=0), 19 \%$ had $\mathrm{FL}=2(26 \%-75 \%$ full $)$ and only $6.2 \%$ of them were full. From the stomachs that contained some food, $79 \%$ presented totally digested contents, the rest being only partially digested.

The results of the diet of $C$. notialis will be presented separately according to the different fishing methods employed.

Considering only the animals collected by bottom trawl, the predominant items in terms of $\mathrm{FO} \%$ were UOM $(79 \%)$ followed by Teleostei $(25 \%)$, Gastropoda (8.3\%) and Ophiuroidea (8.3\%). Without UOM and sediment the AI\% indicates Teleostei as the most important item (99.3\%) (Table 1). For the samples collected by the vessel "Kimpo Maru 58", the few items ingested were UOM, teleostei, sediment, crustaceans and synthetic material (Table 2).

Table 1. Frequency of occurrence (FO\%), biomass abundance $(\mathrm{M} \%)$ and Alimentary Index (AI\%) of items found in foreguts of Chaecon notialis collected with trawl. $\mathrm{N}=24$.

\begin{tabular}{lcccc}
\hline \hline Itens & FO\% & M\% & IA\% & IA\%* \\
\hline $\begin{array}{l}\text { Osteichthyes } \\
\quad \text { Teleostei }\end{array}$ & 25.00 & 30.21 & 12.11 & 99.31 \\
$\begin{array}{l}\text { Mollusca } \\
\text { Gastropoda }\end{array}$ & 8.33 & 0.03 & 0.00 & 0.00 \\
$\quad$ Nematoda & 4.17 & 0.00 & 0.00 & 0.00 \\
$\begin{array}{l}\text { Polychaeta } \\
\quad \text { Nereis sp }\end{array}$ & 4.17 & 0.00 & 0.00 & 0.00 \\
Echinodermata & & & & \\
$\quad$ Ophiuroidea & 8.33 & 0.61 & 0.08 & 0.66 \\
$\quad$ UOM & 79.17 & 43.04 & 54.64 & \\
Sediment & 79.17 & 26.12 & 33.16 & \\
Total & - & - & 100.00 & 100.00 \\
\hline
\end{tabular}

$\mathrm{AI} \% *$ : Alimentary Index calculated without UOM and sediment.

UOM: Undertemined Organic Matter
Table 2. Frequency of occurrence (FO\%), biomass abundance $(\mathrm{M} \%)$ and Alimentary Index (AI\%) of items found in foreguts of Chaecon notialis collected with bottom traps. $\mathrm{N}=8$.

\begin{tabular}{lcccc}
\hline \hline Itens & FO\% & M\% & IA\% & IA\%* \\
\hline Teleostei & 62.50 & 45.97 & 46.75 & - \\
Crustacea & 25.00 & 9.07 & 9.07 & 17.04 \\
UOM & 87.50 & 43.70 & 43.70 & 82.07 \\
Sediment & 37.50 & 0.48 & 0.48 & 0.90 \\
Synthetic & 25.00 & - & - & - \\
material & & & & \\
Total & - & 100.00 & 100.00 & 100.00 \\
\hline
\end{tabular}

AI\%*: Alimentary Index calculated without Teleostei

UOM: Undertemined Organic Matter

The analysis of animals caught with traps using heads and pieces of fish as bait does not permit the quantification of the true importance of teleostei in the diet because the bait itself introduces an error. However, this item occurred in $25 \%$ of the foreguts of C. notialis collected exclusively by bottom trawl, demonstrating that fish are indeed an important resource for this species.

Despite the available sample, the high percentage of stomachs presenting $\mathrm{FL}=0$ and $\mathrm{FL}=1$ found in $C$. notialis suggests that the species presents a low feeding frequency, as appointed by Cartes (1993) for Geryon longipes, another species of the Geryonidae family. One assumption that has been held is that in deep sea environments opportunistic generalists are favored by the lesser availability of food, and that this pattern must become more evident with increasing depth (MARSHAL, 1980). Deep sea crustaceans can endure a lack of food for extended periods of time, as has been demonstrated for Nephrops norvegicus (FARMER, 1975); this ability may be important since the species of geryonid crabs live at depths where food resources are scarcer and more dispersed than in shallower areas. The results of this study reinforce this idea, as demonstrated by the low feeding frequency of Chaceon notialis collected solely by bottom trawl.

The presence of small otoliths and crustaceans in the foreguts of $C$. notialis may be an evidence of predatory activity, as suggested by Cartes (1993).

C. notialis presumably acts as an opportunistic carnivore, presenting the habits both of scavenging and active feeding (i.e. predation). 


\section{ACKNOWLEDGEMENTS}

We thank CNPq (Conselho Nacional de Desenvolvimento Científico e Tecnológico) for providing Domingos with a grant during this research. We are grateful to the General Coordination of the REVIZEE Program, Score-Sul which supported the field investigation.

Our special gratitude is also due to Dr. Edmundo F. Nonato for the identification of polychaetes.

\section{REFERENCES}

ATHIÊ, A. A. R. ; ROSSI-WONGTSCHOWSKI, C. L. D. B Os caranguejos-de-profundidade na Zona Econômica Exclusiva da Região Sudeste-Sul do Brasil: análise das operações de pesca e das capturas do $\mathbf{N} / \mathbf{P}$ "Kinpo Maru n 58". São Paulo: IOUSP, 2004. 64 p. (Série Documentos Revizee - Score Sul).

CARTES, J. E. Diets of deep-sea brachyuran crabs in the Western Mediterranean Sea. Mar. Biol., v. 117, p. 449457, 1993.

FARMER, A. S. D. Synopsis of biological data on the Norway lobster, Nephrops norvegicus (Linnaeus, 1758). FAO Fish. Synopsis, v. 112, p. 1-97, 1975.

HYSLOP, E. J. Stomach contents analysis - a review of methods and their application. J. Fish. Biol., v. 17, p. 411-429, 1980.
KAWAKAMI, E; VAZZOLER, G. Método gráfico e estimativa do índice alimentar aplicado no estudo de alimentação de peixes. Bolm Inst. Oceanogr., S. Paulo, v. 29, n. 2, p. 205-207, 1989.

MANNING, R. B.; HOLTHUIS, L. B. Two new genera and nine new species of geryonid crabs (Crustacea, Decapoda, Geryonidae). Proc. biol. Soc. Wash., v. 102, n. 3, p. 646-650, 1989.

MANNING, R. B.; TAVARES, M. S.; ALBUQUERQUE, E. F. Chaceon ramosae, a new deep-water crab from Brazil (Crustacea: Decapoda: Geryonidae). Proc. biol. Soc. Wash., v. 102, n. 1, p. 50-77, 1989.

MARSHAL, N. B. Developments in deep-sea Biology. London: Blandford, 1980.

ZAVALA-CAMIN, L. A. Introdução aos estudos sobre alimentação natural em peixes. Maringá., $P R$ : EDUEM, 1996. 129 p.

(Manuscript received 10 November 2006; revised 11 June 2006; accepted 05 Julyl 2007) 